\title{
Attachment of Metal Trications to Peptides
}

\author{
Alexandre A. Shvartsburg \\ Pacific Northwest National Laboratory, Richland, Washington, USA \\ Richard C. Jones \\ Chemistry Division, National Center for Toxicological Research, Jefferson, Arkansas, USA
}

Gas-phase complexes of triply charged metal ions with peptides may be readily produced using electrospray ionization, including for small peptides such as bradykinin and peptides with no basic residues such as insulin chain A. Attachment without charge-reduction is demonstrated for all trications studied: $\mathrm{La}^{3+}, \mathrm{Al}^{3+}, \mathrm{Ga}^{3+}, \mathrm{Fe}^{3+}, \mathrm{V}^{3+}$, and $\mathrm{Cr}^{3+}$. The intensities of adducts are often comparable to, or even exceed, those of protonated analogs in any charge state. (J Am Soc Mass Spectrom 2004, 15, 406-408) (c) 2004 American Society for Mass Spectrometry

G as-phase complexes of multiply charged metal cations with organic and biological molecules have become topical over the last decade. In part, this is due to novelty: these systems had essentially been inaccessible for experimentation until the 1990s. A large disparity between the 2nd Ionization Energies (IE) of most metals (15-22 eV for divalent ones except $\mathrm{Ca}, \mathrm{Sr}$, and $\mathrm{Ba}$ ) and 1 st IE of typical organic ligands $(8-13 \mathrm{eV})$ generally causes reduction of dipositive elemental cations in binary collisions with neutrals. This normally prevents a sequential ligation of metal dications in the way standard for singly-charged species: by passage through molecular vapor [1]. The situation is yet worse for trications, as the 3rd IE (IE3) of trivalent metals exceed $19 \mathrm{eV}$. The advent of electrospray (ESI) [2] had enabled the production of gas-phase ligated multiply charged metal ions by transferring them directly from solutions of metal salts in a ligand solvent or appropriate medium containing that ligand [3-13]. Alternatively, one could generate ligated neutrals or monocations as usual, then raise the charge, e.g., via an energetic electron impact [14, 15]. Microsolvation of metal polycations has now been reported for water and many common organic ligands, including alcohols, ethers, ketones, sulfoxides, nitriles, amides, and aromatic compounds. However, almost all this work was for doubly charged species. With a single exception of aldol [9], complexes for trications were observed for few aprotic ligands only-acetone, dimethyl sulfoxide, dimethyl formamide, and acetonitrile [10-13]. Save for DMSO [10], all these were limited to rare-earth metals that have inordinately low IE3.

There has also been much interest in amino acids, peptides, and other biomolecules cationized by metal

Published online January 15, 2004

Address reprint requests to Dr. A. A. Shvartsburg, Pacific Northwest National Laboratory, MSIN K8-98, 3335 Q Avenue, Richland, WA 99352, USA. E-mail: alexandre.shvartsburg@pnl.gov ions. Such complexes often fragment along the pathways that depend on the metal but differ from those for protonated analogs, which sometimes is of analytical utility. For example, lithiated and sodiated peptides eliminate the C-terminal residue [16, 17] (C-terminal sequencing) or cleave at the aspartic acid, if present [18]. Argentinated peptides exhibit a "triplet" product pattern that substantially simplifies their sequencing [19, 20]. When bound to $\mathrm{Zn}^{2+}$, histidine-containing peptides fragment at that residue [21]. Further research into how metal ions coordinate various peptides and modify their dissociation should reveal new phenomena useful in crafting sequencing strategies. However, peptide metalation has been reported only for monocations (of alkali metals and Ag) [22-24] and dications of divalent elements ( $\mathrm{Ca}, \mathrm{Mn}, \mathrm{Zn}, \mathrm{Cu}, \mathrm{Ni}, \mathrm{Co}$ ) [21, 25-28]. No peptides associated with tripositive metal ions have been observed to date. Given that trications in gasphase complexes are reduced by protic ligands (except for the special case of aldol [9], and only rare-earth ions are not reduced even then), one might expect metal trications to be incompatible with peptides. On the other hand, large enough protonated peptides routinely carry charges of +3 and higher, though the protons attach at different sites.

This contribution demonstrates a wholesale complexation of peptides with metal trications, including those of the elements with highest IE3 values. Most experiments were performed using the Finnigan TSQ $7000 \mathrm{ESI} /$ triple quadrupole system. Metalated peptides were generated from aqueous peptide solutions $(\sim 0.1$ $m \mathrm{M})$ doped with trivalent metal salts $(\sim 0.05 \mathrm{mM})$. Nitrates were used for all metals except vanadium: $\mathrm{V}\left(\mathrm{NO}_{3}\right)_{3}$ was not available and $\mathrm{VCl}_{3}$ was substituted. The ESI needle was at $4 \mathrm{kV}$, sheath gas pressure was $\sim 50$ psi, and auxiliary gas was off. The heated capillary was at $200{ }^{\circ} \mathrm{C}$. The voltage drop in lens region was nominal, $\sim 7 \mathrm{~V}$. The infusion rate was $\sim 5 \mu \mathrm{l} / \mathrm{min}$. The 

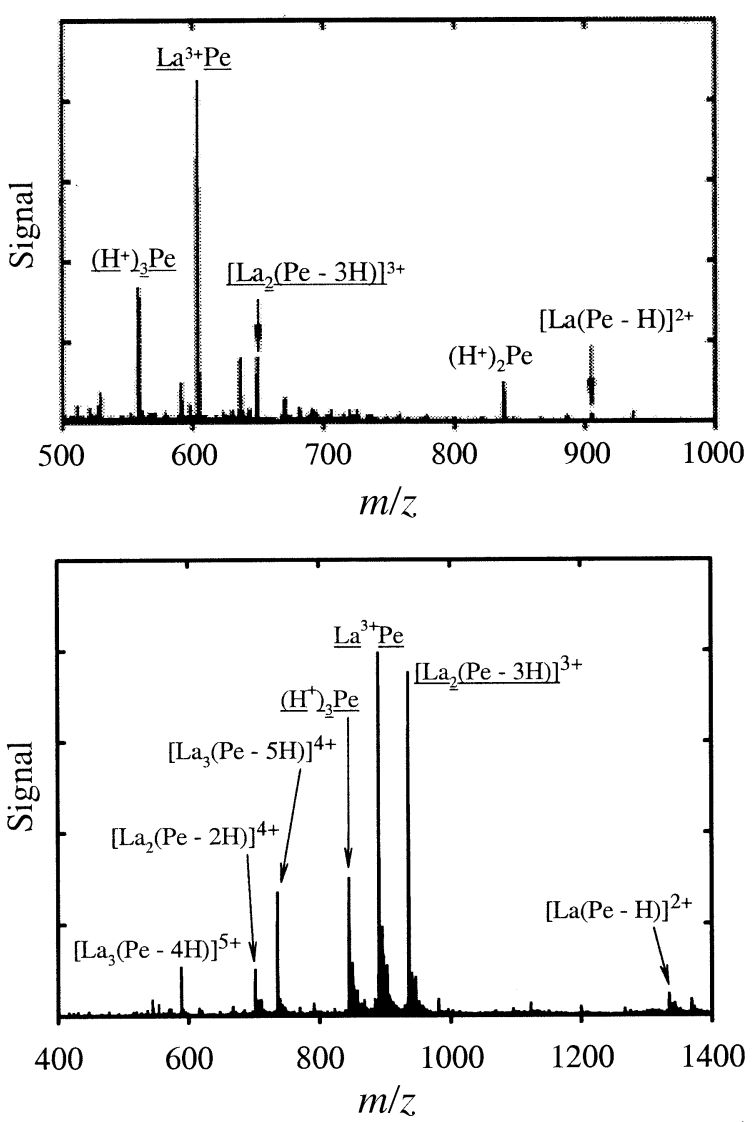

Figure 1. Q1 mass spectral windows for aqueous neurotensin (top panel, TSQ 7000) and insulin chain A (bottom panel, Q/TOF) doped with $\mathrm{La}\left(\mathrm{NO}_{3}\right)_{3}$. Symbol "Pe" stands for peptide. Labels for trications are underlined.

peptides tried were bradykinin (Arg-Pro-Pro-Gly-PheSer-Pro-Phe-Arg, $1060 \mathrm{Da}$ ), human angiotensin I (AspArg-Val-Tyr-Ile-His-Pro-Phe-His-Leu, 1296 Da), neurotensin (pGlu-Leu-Tyr-Glu-Asn-Lys-Pro-Arg-Arg-ProTyr-Ile-Leu, $1673 \mathrm{Da}$ ), and insulin chain A (Gly-Ile-ValGlu-Gln-Cys $\left(\mathrm{SO}_{3} \mathrm{H}\right)-\mathrm{Cys}\left(\mathrm{SO}_{3} \mathrm{H}\right)$-Ala-Ser-Val-Cys $\left(\mathrm{SO}_{3} \mathrm{H}\right)-$ Ser-Leu-Tyr-Gln-Leu-Glu-Asn-Tyr-Cys $\left(\mathrm{SO}_{3} \mathrm{H}\right)$-Asn, $2531 \mathrm{Da})$. To achieve a higher mass resolution and accuracy, some measurements were made employing the Waters/Micromass ESI/Q/TOF instrument. Unlike the TSQ with a regular ESI, this was run with a nanospray source that operates at $\sim 1 \mathrm{kV}$, has a much lower flow rate, and uses no sheath gas. Despite substantially different source conditions, the two instruments produced very similar data.

The ESI of (undoped) aqueous solutions generated customary $\left(\mathrm{H}^{+}\right)_{n}$ (peptide) ions with $n=1-3$ (bradykinin) and $n=2,3$ (angiotensin and neurotensin). Lanthanum has the lowest IE3 of all non-radioactive elements $(19.2 \mathrm{eV})$, so the first set of experiments involved $\mathrm{La}^{3+}$. Ions of $\mathrm{La}^{3+}$ (peptide) composition were immediately observed for all three peptides. The data for neurotensin are presented in Figure 1, top panel. The intensity of metalated ions matches and often exceeds that of protonated analogs. This is potentially impor-

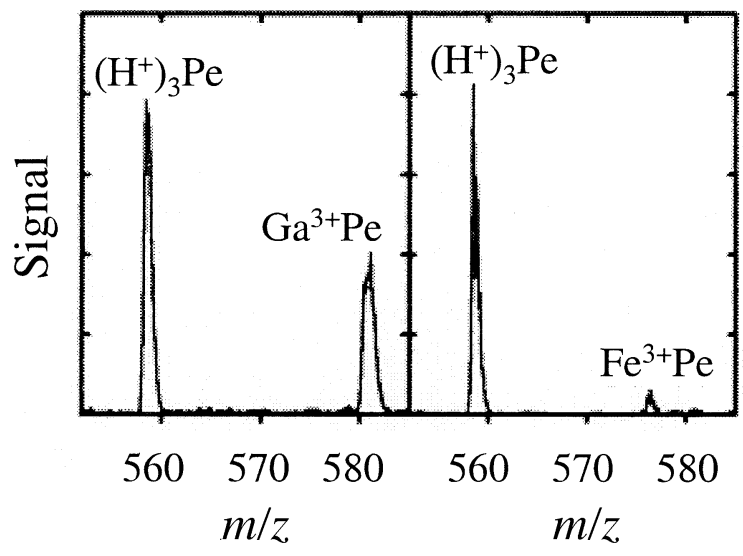

Figure 2. Q1 mass spectral windows (TSQ 7000) for aqueous neurotensin doped with $\mathrm{Ga}\left(\mathrm{NO}_{3}\right)_{3}$ (left panel) and $\mathrm{Fe}\left(\mathrm{NO}_{3}\right)_{3}$ (right panel). Nomenclature follows that in Figure 1.

tant, as the analytically revealing fragmentation patterns of metalated peptides are often of limited practical benefit because of low precursor abundance. For example, the yield of $\mathrm{Ag}^{+}$complexed peptides in ESI tends to be $\sim 10$ times below that of protonated species [19]. The efficiency of $\mathrm{La}^{3+}$ addition might be related to high polarization of peptide by the triple charge, resulting in a stronger bonding. Addition of two metals, forming $\left[\mathrm{La}_{2}(\text { peptide- } 3 \mathrm{H})\right]^{3+}$, proceeds in good yield as well. The $[\mathrm{La}$ (peptide- $\mathrm{H})]^{2+}$ stoichiometry is also present as a minor product. Note that this feature is an order-ofmagnitude weaker than $\left(\mathrm{H}^{+}\right)_{2}$ (peptide), as is standard when peptides add metal mono- or dications.

Each of the three peptides above contains at least two basic residues: two arginines (bradykinin and neurotensin), and arginine and histidine (angiotensin). This raises the question whether a facile complexation of metal trications is limited to peptides with basic side chains. To test that, we have probed insulin chain A-a peptide with no basic side chains but four highly acidic cysteic acid residues. The attachment of $\mathrm{La}^{3+}$ to this peptide (Figure 1, bottom panel) has proven as efficient as that to neurotensin.

Complexation of the doubly (triply) charged metal cations with organic molecules generally becomes more challenging as the 2nd (3rd) IE of the metal increases, because of the growing propensity for charge reduction. For trications, the attachment to some ligands could be achieved only for the Group 3 elements, which have IE3 below $25 \mathrm{eV}[9,13]$. To find out if this holds for peptides, $\mathrm{La}\left(\mathrm{NO}_{3}\right)_{3}$ in the aqueous neurotensin solution was replaced by the salts of trivalent metals outside of Group 3 with high IE3. In the order of increasing IE3, those were $\mathrm{Al}(28.5 \mathrm{eV}), \mathrm{V}(29.3 \mathrm{eV}), \mathrm{Ga}(30.7 \mathrm{eV}), \mathrm{Fe}$ $(30.7 \mathrm{eV})$, and $\mathrm{Cr}(31.0 \mathrm{eV})$. These values are $9-12 \mathrm{eV}$ above the IE3 of La. $\mathrm{M}^{3+}$ (neurotensin) species were found for all metals above, the examples of $\mathrm{Ga}$ and $\mathrm{Fe}$ are shown in Figure 2. However, their intensities relative to those of $\left(\mathrm{H}^{+}\right)_{3}$ (neurotensin) ions were less than they were for La. In particular, yields of metalated 


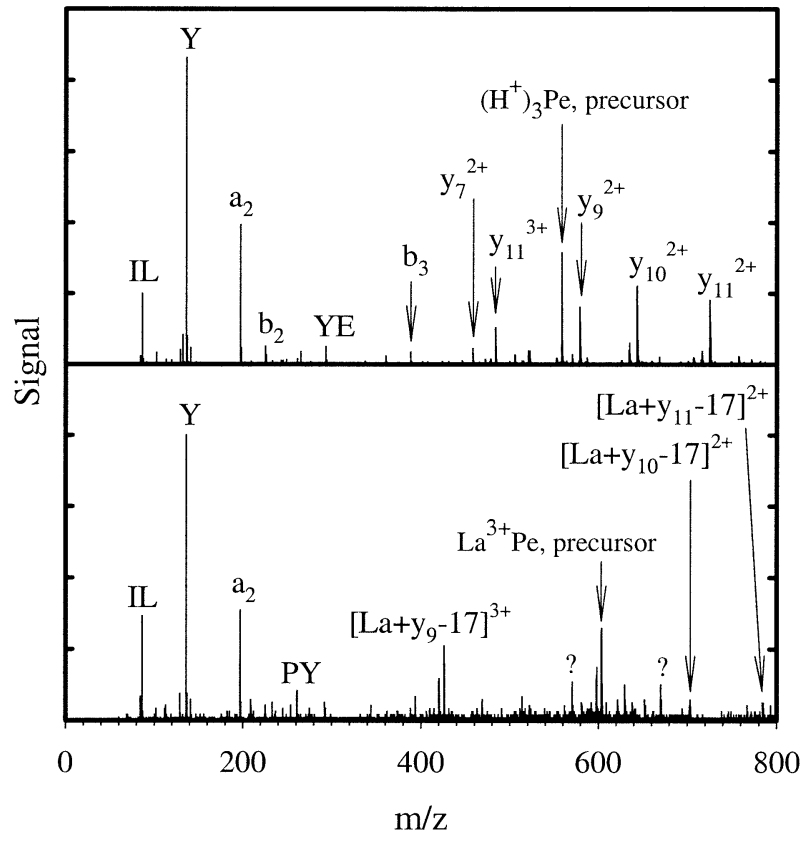

Figure 3. CID spectra $(\mathrm{Q} / \mathrm{TOF})$ of $\left(\mathrm{H}^{+}\right)_{3}$ (neurotensin) (top panel) and $\mathrm{La}^{3+}$ (neurotensin) (bottom panel) measured under identical conditions. The two question marks in the MS/MS spectrum of $\mathrm{La}^{3+}$ (neurotensin) label the unassigned peaks at $m / z=570.3$ and $m / z=670.1$.

peptides did not exceed those of the triply protonated ones. Still $\mathrm{M}^{3+}$ (neurotensin) peaks were prominent for all metals, typically $\sim 10-50 \%$ of the $\left(\mathrm{H}^{+}\right)_{3}$ (neurotensin) features. For metals other than La, no clear correlation between IE3 and the efficiency of $\mathrm{M}^{3+}$ (neurotensin) formation was observed, perhaps due to a narrow range of IE3 values for the elements considered.

We have performed some preliminary experiments on the MS/MS of $\mathrm{M}^{3+}$ (peptide) ions that we produced. The example of $\mathrm{La}^{3+}$ (neurotensin) is presented in Figure 3, bottom panel. Many fragments mirror those of $\left(\mathrm{H}^{+}\right)_{3}$ (neurotensin) (Figure 3, top panel) under the same conditions, but two significant charged products have no apparent analogs in the CID of protonated precursor. Much further work is needed to understand the dissociation of $\mathrm{M}^{3+}$ (peptide) ions and investigate its dependence on the metal nature. (Dissociation pathways of $\mathrm{M}^{3+}$ complexes with simple organic ligands such as DMSO are remarkably metal-specific [10].)

In summary, this communication demonstrates the formation of gas-phase complexes of peptides with metal trications using ESI. These adducts are abundant, in some cases more intense than protonated species in any charge state. The attachment has been observed for all peptides and metals tried, namely four peptides (including a highly acidic one with no basic residues) and six metals: $\mathrm{La}, \mathrm{Al}, \mathrm{V}, \mathrm{Ga}, \mathrm{Fe}$, and $\mathrm{Cr}$. These elements are representative of trivalent metals: They encompass both main group and transition metals, and include metals with IE3 ranging from the lowest $(\mathrm{La}, 19 \mathrm{eV})$ to nearly the highest $(\mathrm{Cr}, 31 \mathrm{eV})$. Three of the peptides tried have 9-13 residues, leading to the conclusion of ubiquitous attachment of metal trications to peptides containing $\sim 10$ residues. This is the characteristic size for peptides in tryptic and other common digests that are routinely sequenced in proteomics applications [19, $20,29,30]$. What the fragmentation pathways are for peptide complexes with metal trications and whether they could be of analytical utility remains to be seen.

\section{Acknowledgments}

The authors gratefully acknowledge illuminating discussions with Dr. Dan Doerge, Dr. Rick Edmondson, and Dr. Keqi Tang.

\section{References}

1. Spears, K. G.; Fehsenfeld, F. C. J. Chem. Phys. 1972, 56, 5698.

2. Fenn, J. B.; Mann, M.; Meng, C. K.; Wong, S. F.; Whitehouse, C. M. Science 1989, 246, 64.

3. Jayaweera, P.; Blades, A. T.; Ikonomou, M. G.; Kebarle, P. J. Am. Chem. Soc. 1990, 112, 2452.

4. Cheng, Z. L.; Siu, K. W. M.; Guevremont, R.; Berman, S. S. J. Am. Soc. Mass Spectrom. 1992, 3, 281.

5. Kohler, M.; Leary, J. A. J. Am. Soc. Mass Spectrom. 1997, 8, 1124.

6. Rodriguez-Cruz, S. E.; Jockusch, R. A.; Williams, E. R. J. Am. Chem. Soc. 1998, 120, 5842.

7. Seto, C.; Stone, J. A. Int. J. Mass Spectrom. Ion Processes 1998, 175, 263.

8. Hall, B. J.; Brodbelt, J. S. J. Am. Soc. Mass Spectrom. 1999, 10, 402.

9. Shvartsburg, A. A. J. Am. Chem. Soc. 2002, 124, 7910.

10. Shvartsburg, A. A. J. Am. Chem. Soc. 2002, 124, 12343.

11. Blades, A. T.; Jayaweera, P.; Ikonomou, M. G.; Kebarle, P. Int. J. Mass Spectrom. Ion Processes 1990, 101, 325.

12. Walker, N. R.; Wright, R. R.; Stace, A. J.; Woodward, C. A. Int. J. Mass Spectrom. 1999, 188, 113.

13. Shvartsburg, A. A. Chem. Phys. Lett. 2002, 360, 479.

14. Walker, N. R.; Wright, R. R.; Stace, A. J. J. Am. Chem. Soc. 1999, 121, 4837.

15. Walker, N.; Dobson, M. P.; Wright, R. R.; Barran, P. E.; Murrell, J. N.; Stace, A. J. J. Am. Chem. Soc. 2000, 122, 11138.

16. Lin, T.; Glish, G. L. Anal. Chem. 1998, 70, 5162.

17. Lin, T.; Payne, A. H.; Glish, G. L. J. Am. Soc. Mass Spectrom. 2001, 12, 497.

18. Lee, S. W.; Kim, H. S.; Beauchamp, J. L. J. Am. Chem. Soc. 1998, 120, 3188.

19. Chu, I. K.; Guo, X.; Lau, T-C.; Siu, K. W. M. Anal. Chem. 1999, $71,2364$.

20. Chu, I. K.; Cox, D. M.; Guo, X.; Kireeva, I.; Lau, T-C.; McDermott, J. C.; Siu, K. W. M. Anal. Chem. 2002, 74, 2072.

21. Hu, P.; Loo, J. A. J. Am. Chem. Soc. 1995, 117, 11314.

22. Grese, R. P.; Gross, M. L. J. Am. Chem. Soc. 1990, 112, 5098.

23. Teesch, L. M.; Orlando, R. C.; Adams, J. J. Am. Chem. Soc. 1991, 113,3668 .

24. Li, H.; Siu, K. W. M.; Guevremont, R.; Le Blanc, J. C. Y. J. Am. Soc. Mass Spectrom. 1997, 8, 781.

25. Loo, J. A.; Hu, P.; Smith, R. D. J. Am. Soc. Mass Spectrom. 1994, $5,959$.

26. Taraszka, J. A.; Li, J.; Clemmer, D. E. J. Phys. Chem. B 2000, 104, 4545.

27. Vaisar, T.; Gatlin, C. L.; Turecek, F. Int. J. Mass Spectrom. Ion Processes 1997, 162, 77.

28. Vaisar, T.; Gatlin, C. L.; Rao, R. D.; Seymour, J. L.; Turecek, F. J. Mass Spectrom. 2001, 36, 306.

29. Valentine, S. J.; Counterman, A. E.; Clemmer, D. E. J. Am. Soc. Mass Spectrom. 1999, 10, 1188.

30. Reynolds, K. J.; Yao, X.; Fenselau, C. J. Proteome Res. 2002, 1, 27. 